\title{
PENGARUH GAYA KEPEMIMPINAN DAN LINGKUNGAN KERJA TERHADAP KINERJA PEGAWAI TELEVISI REPUBLIK INDONESIA STASIUN SULAWESI TENGGARA
}

\author{
Marjan \\ Program Ilmu Ekonomi Pascasarjana Universitas Halu Oleo \\ Email: marjan_budukarim@yahoo.com \\ Rosnawintang \\ Fakultas Ekonomi dan Bisinis Universitas Halu Oleo \\ Email: nanarosnawintang@gmail.com \\ Husin \\ Fakultas Ekonomi dan Bisinis Universitas Halu Oleo \\ Email: husinhusin73@yahoo.com
}

\begin{abstract}
Abstrak
Penelitian bertujuan untuk menguji dan menganalisis pengaruh gaya kepemimpinan dan lingkungan kerja terhadap kinerja pegawai. Studi pada TVRI Stasiun Sulawesi Tenggara. Penelitian ini menggunakan pendekatan kuantitatif. Populasi dan sampelnya adalah seluruh pegawai TVRI Stasiun Sulawesi Tenggara yang berjumlah 92 orang. Teknik pengambilan sampel menggunakan sampling jenuh atau sensus. Metode pengumpulan data menggunakan kuesioner. Sedangkan Analisis data menggunakan analisis statistik deskriptif dan uji kualitas data menggunakan uji reliabilitas dan uji validitas serta uji asumsi klasik. Analisis data diolah dengan bantuan software IBM SPSS 22.

Hasil penelitian menunjukkan bahwa (1) gaya kepemimpinan berpengaruh signifikan terhadap kinerja pegawai; (2) lingkungan kerja berpengaruh signifikan terhadap kinerja pegawai dan (3) pemberian insentif berpengaruh tidak signifikan terhadap kinerja pegawai.
\end{abstract}

\section{Kata kunci: Gaya Kepemimpinan, Lingkungan Kerja, Pemberian Insentif, Kinerja Pegawai}

The research aims to test and analyze the influence of leadership style, work environment and incentives for the performance of TVRI Southeast Sulawesi Station employees. This study uses a quantitative approach. The population and sample are all 92 employees of TVRI Southeast Sulawesi Station. The sampling technique uses saturated sampling. The data collection method uses a questionnaire. While the data analysis uses descriptive statistical analysis and data quality tests using the reliability test and validity test and the classic assumption test. Data analysis was processed with the help of IBM SPSS 22 software.

The results showed that (1) leadership style had a significant effect on employee performance, (2) work environment had a significant effect on employee performance, (3) incentive giving had no significant effect on employee performance.

Keywords: Leadership Style, Work Environment, Giving Incentives, Employee Performance

\section{PENDAHULUAN}

Organisasi merupakan kesatuan sosial yang dikoordinasikan secara sadar dengan sebuah batasan yang reaktif dapat diidentifikasikan, bekerja secara terus menerus untuk mencapai tujuan (Robbins, 2008). Organisasi berisikan orang- orang yang mempunyai serangkaian aktivitas yang jelas dan dilakukan secara berkelanjutan guna mencapai tujuan organisasi. Semua tindakan yang diambil dalam setiap kegiatan diprakarsai dan ditentukan oleh manusia yang menjadi anggota organisasi, dimana manusia sebagai pendukung utama setiap organisasi apapun bentuk organisasi itu (Mulyadi dan Rivai, 2009). 
Jurnal Progres Ekonomi Pembangunan (JPEP)

Volume 5, Nomor 2. Tahun 2020

Page: $1-10$

http://ojs.uho.ac.id/index.php/JPEP

Sumber Daya Manusia (SDM) di dalam suatu organisasi/perusahaan merupakan suatu yang esensial untuk menjalankan roda organisasi/perusahaan/ lembaga guna mencapai tujuannya. Pencapaian suatu organisasi sangat erat kaitannya dengan kualitas kinerja anggota di dalamnya. Untuk memelihara dan memaksimalkan kinerja anggota yang baik ada banyak hal yang mempengaruhinya seperti kesejahteraan, pendidikan dan pelatihan, motivasi, gaya kepemimpinan, budaya organisasi, lingkungan kerja, pemberian insentif, dll.

Kinerja pegawai erat kaitannya dengan penilaian kinerja, untuk itu penilaian kinerja pegawai perlu dilakukan oleh suatu organisasi. Penilaian kinerja (performance evaluation) yaitu proses untuk mengukur atau mengevaluasi hasil pekerjaan yang dilakukan seseorang atau sekelompok orang dalam organisasi (Rivai, 2003). Dengan kata lain penilaian kinerja ditentukan oleh hasil kegiatan sumber daya manusia (SDM) dengan standar kinerja yang telah ditetapkan organisasi sebelumnya.

Kinerja pegawai yang baik dapat menghasilkan sebuah hasil pencapaian atau produktivitas yang tinggi begitupun sebaliknya, karenanya seorang pemimpin organisasi harus memperhatikan kinerja anggotanya. Salah satu masalah yang dihadapi oleh organisasi dalam upaya mewujudkan tujuannya adalah menyangkut sumber daya manusia yang menjadi pilar penyangga utama sekaligus penggerak roda organisasi. Dengan kata lain tercapainya tujuan organisasi ditentukan oleh kualitas dan efektivitas sumber daya manusia yang dalam organisasi disebut pegawai atau karyawan. Kinerja yang didefinisikan sebagai "perilaku atau tindakan yang relevan dengan tujuan organisasi dan sebagai kemampuan dimana individu melakukan inti substantif atau teknis dari tugas pusatnya. (Koopmans et al, 2014)

Setiap organisasi berupaya untuk mencapai tujuan secara maksimal. Olehnya, dalam upaya pencapaian tujuan tersebut, diperlukan pemimpin yang efektif, lingkungan kerja yang kondusif, trust dan komitmen tugas. Dengan kata lain bahwa keberhasilan suatu organisasi dalam mencapai tujuan tergantung pada bagaimana seorang pemimpin secara efektif mempengaruhi perilaku orang yang dipimpin agar berhasil dalam kerja sama dan sama-sama bekerja.

Mulyadi dan Rivai (2009) memaparkan bahwa pemimpin dalam kepemimpinannya perlu memikirkan dan memperlihatkan gaya kepemimpinan yang akan diterapkan kepada pegawainya. Gaya kepemimpinan yaitu norma perilaku yang digunakan oleh seseorang pada saat orang tersebut mencoba mempengaruhi perilaku orang lain (Handoko, 2003). Gaya kepemimpinan atasan dapat mempengaruhi kesuksesan pegawai dalam berprsetasi (Suranta, 2002). Dengan kata lain gaya kepemimpinan atasan dapat berpengaruh pada kinerja pegawai dalam suatu organisasi. Disamping itu untuk mampu menciptakan pegawai yang memiliki kinerja yang tinggi, maka salah satu aspek yang tak kalah penting untuk diperhatikan adalah masalah lingkungan kerja. Menurut Doelhadi (2001) lingkungan kerja merupakan faktor penting dan berpengaruh terhadap pegawai dalam melakukan pekerjaannya. Pegawai sangat peduli sekali dengan lingkungan kerjanya baik untuk kenyamanan pribadi maupun untuk memudahkan mengerjakan tugas dengan baik.

Kondisi lingkungan kerja yang baik berpengaruh dalam meningkatkan kepuasan kerja pegawai karena peran penting dalam mengurangi rasa cepat lelah serta menghilangkan atau mengurangi rasa bosan sehingga semangat kerja meningkat, betah ditempat kerja dan bertanggung jawab dalam melaksanakan tugasnya. Begitu juga dengan lingkungan non fisik yang baik, seperti terpenuhinya kebutuhan pegawai, pedoman kerja yang jelas, hubungan yang harmonis antara pegawai dengan rekan kerja dan atasannya, dapat menimbulkan rasa nyaman pada pegawai sehingga kinerjanya meningkat.

Namun beberapa hasil penelitian sebelumnya masih terdapat pertentangan terkait gaya kepemimpinan, lingkungan kerja dan pemberian insentif terhadap peningkatan kinerja pegawai. mengingat pentingnya gaya kepemimpinan, lingkungan kerja dan pemberian insentif untuk dikaji, banyak peneliti yang telah melakukan studi yang serupa dengan penelitian ini 
Jurnal Progres Ekonomi Pembangunan (JPEP)

Volume 5, Nomor 2. Tahun 2020

Page: $1-10$

http://ojs.uho.ac.id/index.php/JPEP

diantaranya: Rani Mariam (2009); Hentry Sukmasari (2011); Hardino Febriansyah Putra (2012); Fretilino Rufino De, A.P (2012); Noack Pariaribo (2014); Windy Sitorus (2016); Erlina Sintia Dewi (2018); Sri Wayati (2018); dan lain-lain.

Penelitian ini bertujuan untuk menganalisis dan mengetahui: (1) Pengaruh gaya kepemimpinan terhadap kinerja pegawai TVRI Stasiun Sulawesi Tenggara dan (2) Pengaruh lingkungan kerja terhadap kinerja pegawai TVRI Stasiun Sulawesi Tenggara.

\section{KAJIAN PUSTAKA DAN KERANGKA KONSEP Kinerja Pegawai}

Kinerja adalah hasil-hasil fungsi pekerjaan seseorang atau sekelompok dalam suatu periode waktu tertentu yang merefleksikan seberapa baik seseorang atau kelompok tersebut memenuhi persyaratan sebuah pekerjaan dalam usaha pencapaian tujuan organisasi (Bernardin dan Russell, 2002). Menurut Mangkunegara (2010) kinerja merupakan hasil kerja secara kualitas dan kuantitas yang dicapai oleh seorang karyawan dalam melaksanakan tugasnya sesuai dengan tanggung jawab yang diberikan kepadanya. Kasmir (2016) mengatakan kinerja merupakan hasil kerja dan perilaku kerja yang telah dicapai dalam menyelesaikan tugas-tugas dan tanggung jawab yang diberikan dalam suatu periode tertentu. Meningkatnya kinerja perorangan (individual performance) maka kemungkinan besar juga akan meningkatkan kinerja perusahaan (coorporate performance) karena keduanya mempunyai hubungan yang erat.

Dari beberapa definisi di atas, dapat disimpulkan bahwa kinerja merupakan hasil kerja yang dicapai oleh seseorang atau sekelompok orang dalam suatu organisasi atau perusahaan secara kualitas dan kuantitas pada periode tertentu yang merefleksikan seberapa baik seseorang atau kelompok tersebut memenuhi persyaratan sebuah pekerjaan dalam usaha pencapaian tujuan organisasi atau perusahaan.

Arif Ramdhani (2011) menjelaskan terdapat delapan dimensi pengukuran kinerja menurut teori Dessler yaitu: (1) pemahaman pekerjaan/kompetensi; (2) kualitas/kuantitas kerja; (3) perencanaan/organisasi; (4) inisiatif/komitmen; (5) penyelesaian masalah/kreativitas; (6) kerja tim dan kerja sama; (7) kemampuan berhubungan dengan orang lain; (8) komunikasi (lisan dan tulisan). Faktor-faktor yang mempengaruhi kinerja pegawai baik hasil maupun perilaku kerja menurut Kasmir (2016) yaitu: kemampuan dan keahlian, pengetahuan, rancangan kerja, kepribadian, motivasi kerja, kepemimpinan, gaya kepemimpinan, budaya organisasi, kepuasan kerja, lingkungan kerja disekitar, loyalitas, komitmen dan disiplin kerja.

Dari beberapa faktor yang mempengaruhi kinerja pegawai diatas peneliti hanya mengangkat dua faktor yang telah disesuaikan dengan keadaan obyek penelitian, yaitu faktor gaya kepemimpinan dan lingkungan kerja.

\section{Gaya Kepemimpinan}

Gaya kepemimpinan menurut V. Rivai dan Dedy Mulyadi (2009) gaya kepemimpinan adalah sekumpulan ciri yang digunakan pimpinan untuk mempengaruhi bawahan agar sasaran organisasi tercapai atau dapat pula dikatakan bahwa gaya kepemimpinan adalah pola perilaku dan strategi yang disukai dan sering diterapkan oleh seorang pemimpin. Selanjutnya gaya kepeimimpinan menurut Thoha dalam Harbani Pasolong (2010) merupakan norma perilaku yang digunakan oleh seseorang pada saat orang tersebut mencoba mempengaruhi perilaku orang lain.

Menurut Hasibuan (2014), terdapat beberapa macam gaya kepemimpinan, yaitu sebagai berikut: Kepemimpinan Otoriter, Kepemimpinan Partisipatif dan Kepemimpinan Delegasi. dari tiga gaya kepemimpin tersebut, gaya kepemimpinan partisipatif lebih tepat digunakan pada kondisi lingkungan perusahaan atau lembaga yang menuntut kreatifitas, dukungan dan motivasi kerja yang tinggi dari para pegawainya. Disamping itu gaya kepemimpinan partisipatif ini cocok diterapkan bagi pimpinan yang selalu mengharapkan saran dari pegawai untuk pengambilan keputusan dalam upaya meningkatkan produktivitas perusahaan. Gaya kepemimpinan 
Jurnal Progres Ekonomi Pembangunan (JPEP)

Volume 5, Nomor 2. Tahun 2020

Page: $1-10$

http://ojs.uho.ac.id/index.php/JPEP

partisipatif merupakan sarana komunikasi yang efektif untuk menjalin komunikasi yang terbuka antara pemimpin dan pegawai. Menurut Hasibuan (2014) kepemimpinan partisipatif dapat diukur dengan menggunkan tiga indikator, yaitu: (1) Konsultasi; (2) Keputusan bersama dan (3) Pendelegasian.

\section{Lingkungan Kerja}

Lingkungaan kerja menyangkut tempat kerja, tata-letak peralatan, ruangan kerja, cahaya, ventilasi atau sirkulasi udara, alat penjaga keselamatan dan kesehatan kerja (Payaman J. Simanjuntak. 2011) Dengan kata lain lingkungan kerja mempengaruhi tingkat kinerja seseorang. Menurut Alex S. Nitisemito (2000) mendefinisikan sebagai berikut "lingkungan kerja adalah segala sesuatu yang ada disekitar para pekerja yang dapat mempengaruhi dirinya dalam menjalankan tugas-tugas yang diemban.

Menurut Sedarmayanti (2002) menyatakan bahwa secara garis besar, jenis lingkungan kerja terbagi menjadi 2 (dua) yaitu: (1) Lingkungan kerja fisik dan (2) Lingkungan Kerja Non Fisik. Berikut ini beberapa faktor yang diuraikan Sedarmayanti (2001) yang dapat mempengaruhi terbentuknya suatu kondisi lingkungan kerja dikaitkan dengan kemampuan pegawai, diantaranya adalah: Penerangan/Cahaya di Tempat Kerja, Temperatur di Tempat Kerja, Kelembaban di Tempat Kerja, Sirkulasi Udara di Tempat Kerja, Kebisingan di Tempat Kerja, Getaran Mekanis di Tempat Kerja, Bau-bauan di Tempat Kerja, Tata Warna di Tempat Kerja, Dekorasi di Tempat Kerja, Musik di Tempat Kerja dan Keamanan di Tempat Kerja.

\section{Kerangka Konsep}

Kerangka Konseptual yang digunakan dalam penelitian ini merupakan kajian yang mendalam, baik berdasarkan teori maupun kajian empiris hubungan kausal gaya kepemimpinan, lingkungan kerja, pemberian insentif dan kinerja pegawai. Kerangka konseptual dibangun dari rumusan masalah, kajian literatur setiap variabel dan pola hubungan yang dibentuk oleh variabel tersebut. Beberapa penelitian terdahulu menunjukan bahwa gaya kepemimpinan dan lingkungan kerja merupakan variabel independen dalam kinerja pegawai. Sehingga dapat dirumuskan kerangka konsep sebagai berikut:

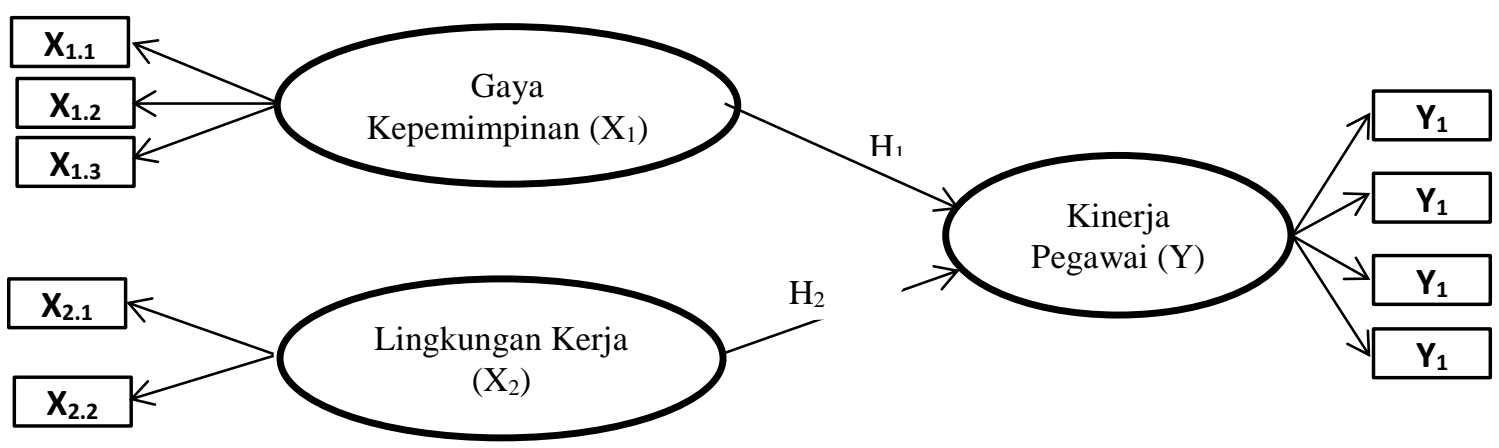

\section{Gambar 1. Skema Kerangka Konsep}

\section{METODE PENELITIAN}

Penelitian ini adalah penelitian dasar (basic researc) merupakan metode penelitian yang digunakan untuk mengembangkan teori dan tidak memperhatikan kegunaan yang langsung bersifat praktis (Sugiyono, 2014). Desain penelitian ini digunakan untuk memberikan bukti empiris dan menganalisis tentang variabel yang dihipotesiskan. Variabel dalam penelitian ini terdiri dari variabel bebas dan variabel terikat. Dimana variabel bebasnya terdiri dari Gaya Kepemimpinan $\left(\mathrm{X}_{1}\right)$ dan Lingkungan Kerja $\left(\mathrm{X}_{2}\right)$. Sedangkan variabel terikatnya adalah kinerja pegawai (Y). 
Jurnal Progres Ekonomi Pembangunan (JPEP)

Volume 5, Nomor 2. Tahun 2020

Page: $1-10$

http://ojs.uho.ac.id/index.php/JPEP

Penelitian ini menggunakan dua macam analisis, metode statistik deskriptif dan statistik inferensial terhadap data yang diperoleh dilapangan. Metode ini bertujuan untuk mendeskripsikan atau menggambarkan data yang telah terkumpul sebagaimana adanya tanpa bermaksud membuat kesimpulan yang berlaku untuk umum atau generalisasi, seperti penyajian data melalui tabel, grafik, diagram lingkaran (pie chart), perhitungan penyebaran data melalui perhitungan rata-rata dan persentase (Sugiyono: 2014). Selanjutnya digunakan inferensial untuk melihat kuat lemahnya pengaruh antar variabel bebas dengan variabel terikat, yaitu dengan cara menganalisis terhadap data yang telah diberi skor sesuai dengan skala pengukuran yang telah ditetapkan, melalui suatu formula statistik. Analisis statistik deskriptif dimaksudkan untuk mendeskripsikan variabel Gaya Kepemimpinan, Lingkungan Kerja dan kinerja pegawai dengan menggunakan bantuan tabel frekuensi/presentase. Analisis statistik inferensial dimaksudkan untuk menguji hipotesis, diringkas dalam analisis variabel ditinjau dari mean dan PCA (Principle Component Analysis) analisis regresi dan uji asumsi klasik.

\section{HASIL PENELITIAN DAN PEMBAHASAN}

\section{Analisis Variabel Ditinjau dari Mean dan Principle Component Analisis (PCA)}

Bagian ini menjelaskan perbandingan antara mean dan rata-rata indikator hasil analisis faktor dengan menggunakan program SPSS. Hal ini dimaksudkan untuk mendeskripsikan setiap indikator yang memberikan kontribusi yang signifikan sebagai pembentuk variabel. Nilai ratarata yang mencermin persepsi responden terhadap indikator penelitian, sedangkan nilai analisis faktor mengambarkan kontribusi indikator dalam membentuk variabel. Hal ini dimaksudkan untuk mendeskripsikan setiap indikator yang memberikan kontribusi yang signifikan sebagai pembentuk variabel. Nilai rata-rata yang mencermin persepsi responden terhadap indikator penelitian, sedangkan nilai analisis faktor mengambarkan kontribusi indikator dalam membentuk variabel. Persepsi responden terhadap indikator-indikator variabel penelitian ditinjau dari mean dan nilai analisis faktor dapat dilihat pada Tabel 1.

\section{Tabel 1}

\section{Perbandingan Nilai Mean dan Analisis Faktor}

\begin{tabular}{clcc}
\hline No. & \multicolumn{1}{c}{ Variabel/Indikator } & Mean & PCA (Analisis Faktor) \\
\hline 1 & Gaya Kepempiman $\left(\mathbf{X}_{1}\right)$ & $\mathbf{4 . 2 2}$ & \\
& Konsultasi $\left(\mathrm{X}_{1.1}\right)$ & $\mathbf{4 . 3 2}$ & 0.798 \\
& Keputusan Bersama $\left(\mathrm{X}_{1.2}\right)$ & 4.06 & $\mathbf{0 . 8 2 0}$ \\
& Pendelegasian $\left(\mathrm{X}_{1.3}\right)$ & 4.29 & 0.733 \\
\hline 2 & Lingkungan Kerja $\left(\mathbf{X}_{2}\right)$ & $\mathbf{4 . 2 3}$ & \\
& Lingkungan Kerja Fisik $\left(\mathrm{X}_{2.1}\right)$ & 4.07 & $\mathbf{0 . 8 5 8}$ \\
& Lingkungan Kerja Non Fisik $\left(\mathrm{X}_{2}\right)$ & $\mathbf{4 . 3 9}$ & $\mathbf{0 . 8 5 8}$ \\
\hline 3 & Kinerja Pegawai $(\mathbf{Y})$ & $\mathbf{4 . 2 5}$ & \\
& Kompetensi $\left(\mathrm{Y}_{1.1}\right)$ & 4.34 & 0.784 \\
Kualitas/Kuantitas Pekerjaan $\left(\mathrm{Y}_{1.2}\right)$ & 4.24 & 0.699 \\
Perencanaan $\left(\mathrm{Y}_{1.3}\right)$ & 4.04 & 0.565 \\
Inisiatif $\left(\mathrm{Y}_{1.4}\right)$ & 4.11 & 0.707 \\
Penyelesaian Masalah $\left(\mathrm{Y}_{1.5}\right)$ & $\mathbf{4 . 3 5}$ & 0.835 \\
& Kerja Tim $\left(\mathrm{Y}_{1.6}\right)$ & 4.27 & 0.826 \\
Kemampuan Hubungan dengan orang lain $\left(\mathrm{Y}_{1.7}\right)$ & 4.32 & $\mathbf{0 . 8 7 1}$ \\
Komunikasi $\left(\mathrm{Y}_{1.8}\right)$ & 4.30 & 0.773 \\
\hline
\end{tabular}

Sumber: Data Primer Diolah, 2020

Berdasarkan tabel diatas, pada variabel gaya kepemimpinan indikator konsultasi terlihat dominan dengan nilai Mean rerata 4.32. Sedangkan uji nilai PCA menunjukan indikator keputusan bersama dengan nilai 0.820 merupakan indikator penting dan mempunyai nilai tertinggi dalam membentuk variabel gaya kepemimpinan. Variabel lingkungan kerja indikator lingkungan kerja non fisik terlihat dominan dengan nilai Mean rerata 4.39. Sedangkan uji nilai 
Jurnal Progres Ekonomi Pembangunan (JPEP)

Volume 5, Nomor 2. Tahun 2020

Page: $1-10$

http://ojs.uho.ac.id/index.php/JPEP

PCA menunjukan bahwa kedua indikator yakni lingkungan kerja fisik dan lingkungan kerja non fisik memperoleh nilai yang sama sebesar 0.858 , artinya bahwa kedua indikator merupakan indikator penting dan mempunyai nilai yang sama dalam membentuk variabel lingkungan kerja.

Pada variabel kinerja pegawai indikator penyelesaian masalah terlihat dominan dengan nilai Mean rerata 4.35. Sedangkan uji nilai PCA untuk variabel kinerja pegawai menunjukan bahwa indikator kemampuan berhubungan dengan orang lain dengan nilai 0.871 merupakan indikator penting dan mempunyai nilai tertinggi dalam membentuk variabel kinerja pegawai.

Analisis Regresi

Berdasarkan hasil pengolahan data, Gaya Kepemimpinan dan Lingkungan Kerja berpengaruh signifikan terhadap Kinerja Pegawai. Hal ini dapat dilihat pada hasil pengolahn data dengan menggunakan SPSS pada Tabel 2.

\section{Tabel 2}

Hasil Regresi Linear Berganda

\begin{tabular}{rccc}
\hline \multicolumn{1}{c}{ Parameter } & Koefisien & t-Statistik & Sig. \\
\hline Konstanta & 0.600 & 1.813 & 0.073 \\
Gaya Kepemimpinan (X1) & 0.318 & 2.889 & 0.005 \\
Lingkungan Kerja (X2) & 0.545 & 5.085 & 0.000 \\
\hline F-Statistik & 62.263 \\
\hline & Sig. F. Statistik & 0.000 \\
\hline Durbin Watson & 0.957 \\
\hline R & 0.764 \\
\hline
\end{tabular}

Sumber: Data Primer Diolah, 2020

Berdasarkan Tabel 2 maka persamaan regresi berganda yang menyatakan pengaruh gaya kepemimpinan $\left(\mathrm{X}_{1}\right)$, lingkungan kerja $\left(\mathrm{X}_{2}\right)$ terhadap kinerja pegawai $(\mathrm{Y})$ dapat dinyatakan sebagai berikut:

\section{$\mathrm{Y}=0.600+0.318 \mathrm{X}_{1}+0.545 \mathrm{X}_{2}$}

Berdasarkan Tabel 2 menunjukan bahwa nilai koefisien korelasi (R) adalah sebesar 0.764 yang berarti bahwa keeratan antara variabel $\mathrm{X}_{1}, \mathrm{X}_{2}$,terhadap $\mathrm{Y}$ dengan nilai yang mendekati 1 . Hal ini menunjukan bahwa hubungan langsung antara gaya kepemimpinan dan lingkungan kerja terhadap kinerja pegawai dikategorikan sangat erat. Nilai koefisien Determinasi $\left(R^{2}\right)$, berdasarkan hasil estimasi pada Tabel 2 dapat dilihat bahwa nilai $\mathrm{R}^{2}$ (R-Square) yaitu sebesar 0.583 dengan persentase sebesar 58,30\%. Hal ini menunjukan bahwa variasi perubahan terhadap variabel Kinerja Pegawai $(\mathrm{Y})$ yang dijelaskan oleh variabel gaya kepemimpinan $\left(\mathrm{X}_{1}\right)$ dan lingkungan kerja $\left(\mathrm{X}_{2}\right)$ yaitu sebesar $58,30 \%$ sedangkan $41,70 \%$ lainnya dari variasi perubahan variabel kinerja pegawai $(\mathrm{Y})$ yang dijelaskan oleh variabel lain yang belum termasuk dalam model penelitian ini.

\section{Uji Normalitas Data}

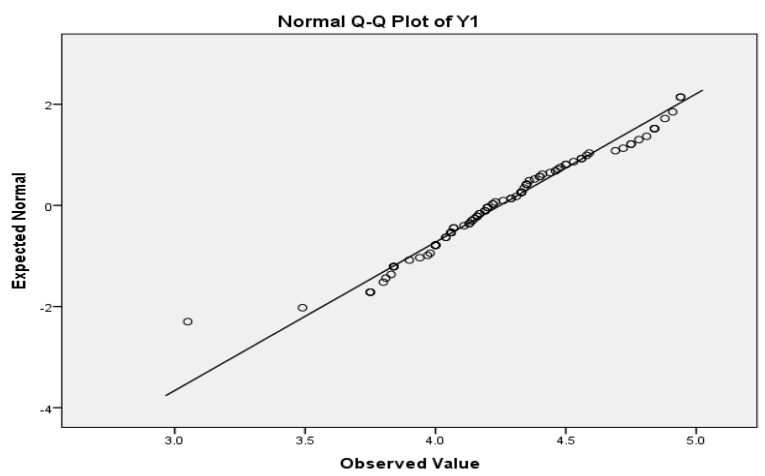

Gambar 2 Hasil Uji Normalitas 
Jurnal Progres Ekonomi Pembangunan (JPEP)

Volume 5, Nomor 2. Tahun 2020

Page: $1-10$

http://ojs.uho.ac.id/index.php/JPEP

Dari gambar 2 menunjukan hasil bahwa model regresi penelitian ini memenuhi asumsi normalitas, karena titik-titik (data) menyebar disekitar garis diagonal dan mengikuti arah garis diagonal. Sehingga dapat disimpulkan bahwa data penelitian berdistribusi normal.

\section{Uji Heteroskedastisitas}

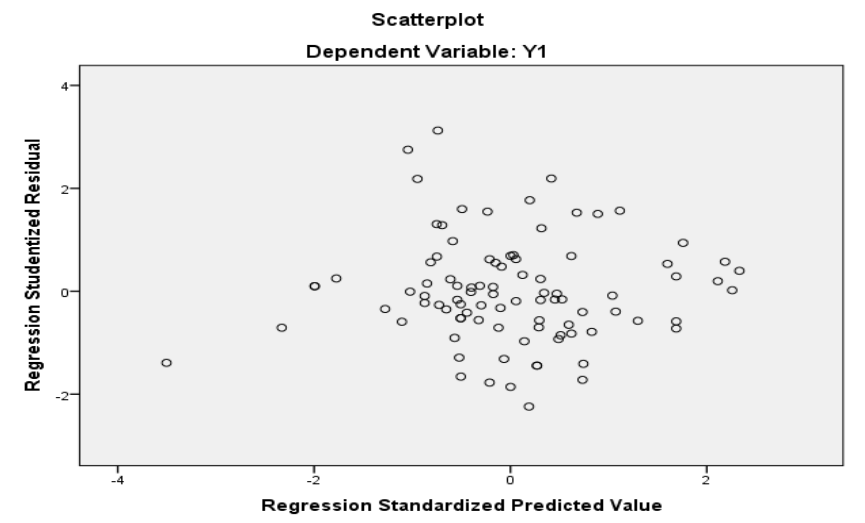

Gambar 3 Hasil Uji Heteroskedastisitas

Pengujian asumsi heterokedastisitas menyimpulkan bahwa model regresi tidak terjadi heteroskedastisitas. Kesimpulan ini diperoleh dengan melihat penyebaran titik-titik yang menyebar secara acak, tidak membentuk sebuah pola tertentu yang jelas, serta tersebar baik diatas maupun dibawah angka 0 pada sumbuh $Y$.

\section{Uji Hipotesis}

\section{Pengaruh Gaya Kepemimpinan Terhadap Kinerja Pegawai}

Berdasarkan tabel pengolahan data, diperoleh bahwa nilai koefisien regresi pengaruh gaya kepemimpinan terhadap kinerja pegawai sebesar 0.318 dan probability sebesar 0.005 . nilai signifikan probability sebesar 0.005 lebih kecil dari nilai alpha 5\% (0.05). Dengan demikian, maka hipotesis 1 diterima sehingga dapat disimpulkan bahwa pada tingkat keyakinan 95\% dapat dinyatakan bahwa gaya kepemimpinan berpengaruh signifikan terhadap kinerja pegawai

\section{Pengaruh Lingkungan Kerja Terhadap Kinerja Pegawai}

Berdasarkan tabel pengolahan data, diperoleh bahwa nilai koefisien regresi pengaruh lingkungan kerja terhadap kinerja pegawai sebesar 0.545 dan probability sebesar 0.000 . Nilai signifikan probability sebesar 0.000 lebih kecil dari nilai alpha 5\% (0.05). Dengan demikian, maka hipotesis 1 diterima sehingga dapat disimpulkan bahwa pada tingkat keyakinan 95\% dapat dinyatakan bahwa lingkungan kerja berpengaruh signifikan terhadap kinerja pegawai

\section{Pembahasan}

Dengan menggunakan perhitungan uji regresi linear berganda diperoleh nilai $R$ square sebesar 0.583. Sehinggga dapat disimpulkan bahwa kinerja pegawai dapat dijelaskan oleh variabel gaya kepemimpinan $\left(X_{1}\right)$ dan lingkungan kerja $\left(X_{2}\right)$ sebesar $58,3 \%$ dan $41,7 \%$ sisanya dijelaskan oleh variabel lain diluar model.

\section{Pengaruh gaya kepemimpinan terhadap kinerja pegawai TVRI Stasiun Sulawesi Tenggara}

Berdasarkan hasil analisis statistik menunjukan bahwa gaya kepemimpinan TVRI Stasiun Sulawesi Tenggara diperoleh nilai koefisien sebesar 0.318 dan nilai signifikan 0.005 atau dibawah nilai 0.05 , sehingga dapat disimpulkan bahwa pada tingkat keyakinan $95 \%$ dapat dinyatakan bahwa gaya kepemimpinan berpengaruh signifikan terhadap kinerja pegawai. Hasil penelitian ini diketahui bahwa secara parsial gaya kepemimpinan berpengaruh signifikan terhadap kinerja pegawai TVRI Stasiun Sulawesi Tenggara. 
Jurnal Progres Ekonomi Pembangunan (JPEP)

Volume 5, Nomor 2. Tahun 2020

Page: $1-10$

http://ojs.uho.ac.id/index.php/JPEP

Hasil analisis tersebut dapat dijelaskan berdasarkan data pada Tabel 1 bahwa rerata persepsi responden atas pengaruh gaya kepemimpinan pada kinerja pegawai adalah 4,22 (kategori positif/baik). Pada variabel gaya kepemimpinan indikator keputusan bersama dominan dengan hasil mean dari indikator tersebut menunjukan rerata 4,23. Hasil uji nilai PCA untuk variabel gaya kepemimpinan terlihat bahwa keputusan bersama dengan nilai 0,820 merupakan indikator penting dan mempunyai nilai tertinggi dalam membentuk variabel gaya kepemimpinan. Hal tersebut dapat disimpulkan bahwa seharusnya pegawai lebih meningkatkan pemanfaatan pegambilan keputusan bersama menjadi paktor utama yang membentuk variabel gaya kepemimpinan partisipatif.

Meskipun hasil penelitian variabel gaya kepemimpinan menunjukan hasil positif (baik), tapi masih perlu memperbaiki gaya kepemimpinan dengan cara konsultasi. Hal ini karena memiliki mean terenda $(4,21)$, sementara hasil uji nilai PCA menunjukan nilai 0.798 yang berarti bahwa indikator konsultasi mencapai peringkat kedua setelah indikator keputusan bersama menempati peringkat paling penting.

Berdasarkan hasil analisis di atas, dapat dikatakan bahwa semakin baik cara pemimpin berkonsultasi, semakin baik cara pemimpin dalam mengambil keputusan dan semakin baik cara pemimpin dalam menjalin relasi dengan pegawai maka akan meningkatkan kinerja pegawai TVRI Stasiun Sulawesi Tenggara.

Secara empiris hasil penelitian mendukung hasil penelitian terdahulu yang dilakukan oleh Nova Nurwawilis (2008) menyatakan bahwa Gaya kepemimpinan berpengaruh signifikan terhadap kinerja Pegawai di RSUD Rokan Hulu Provinsi Riau. Yulniwarti Shimko (2012), menyatakan bahwa terdapat pengaruh yang siginifikan antara gaya kepemimpinan terhadap kinerja pegawai negeri sipil pada Kantor Pemerintah Daerah Kabupaten Solok Selatan, Sumatera Barat. Demikian juga penelitian yang dilakukan Noack Pariaribo (2014) menyatakan bahwa Gaya kepemimpinan berpengaruh signifikan terhadap kinerja pegawai Pada Badan Perencanan Pembangunan Daerah di Kabupaten Supiori. Begitu juga hasil penelitian.

\section{Pengaruh lingkungan kerja terhadap kinerja pegawai TVRI Stasiun Sulawesi Tenggara}

Berdasarkan hasil analisis statistik menunjukan bahwa lingkungan kerja TVRI Stasiun Sulawesi Tenggara diperoleh nilai koefisien sebesar 0.543 dan nilai signifikan 0.000 atau dibawah nilai 0.05 , sehingga dapat disimpulkan bahwa pada tingkat keyakinan $95 \%$ dapat dinyatakan bahwa lingkungan kerja berpengaruh positif dan signifikan terhadap kinerja pegawai. Hasil penelitian ini diketahui bahwa secara parsial lingkungan kerja berpengaruh positif dan signifikan terhadap kinerja pegawai TVRI Stasiun Sulawesi Tenggara.

Hasil analisis tersebut dapat dijelaskan berdasarkan data pada Tabel 1 bahwa rerata persepsi responden atas pengaruh lingkungan kerja pada kinerja pegawai adalah 4,23 (kategori positif/baik). Pada variabel lingkungan kerja indikator lingkungan kerja fisik dan non fisik masing-masing memperoleh hasil mean rerata 4,23. Hasil uji nilai PCA untuk variabel lingkungan kerja terlihat bahwa lingkungan kerja fisik dan non fisik dengan nilai 0,885 keduanya merupakan indikator penting dan mempunyai nilai yang sama dalam membentuk variabel lingkungan kerja. Hal tersebut dapat disimpulkan bahwa seharusnya pegawai lebih memperhatikan lingkungan kerja fisik dan non fisik menjadi paktor utama yang membentuk variabel lingkungan kerja.

Secara empiris hasil penelitian mendukung hasil penelitian terdahulu yang dilakukan oleh Fretilino Rufino De, A.P (2012) hasil penelitian menyatakan bahwa Lingkungan kerja secara signifikan berpengaruh kinerja karyawan Grand Manhattan Club. Sri Kurniawati (2014) menyatakan bahwa lingkungan kerja berpengaruh positif terhadap kinerja karyawan Koperasi Mahasiswa (Kopma) di Kabupaten Sleman. Ramma Indra Pramuji (2017) Terdapat hubungan yang positif dan signifikan antara lingkungan kerja dengan kinerja karyawan pada Dinas Kepemudaan dan Olahraga Kabupaten Indramayu. Ichsan Kasnul (2018) Hasil pengujian hipotesis membuktikan bahwa lingkungan kerja memiliki pengaruh positif dan signifikan 
Jurnal Progres Ekonomi Pembangunan (JPEP)

Volume 5, Nomor 2. Tahun 2020

Page: $1-10$

http://ojs.uho.ac.id/index.php/JPEP

terhadap peningkatan kinerja pegawai pada PT. Gapura Angkasa di Bandara International Sultan Hasanuddin Makassar.

\section{KESIMPULAN DAN SARAN \\ Kesimpulan}

Berdasarkan hasil penelitian dan pembahasan tentang pengaruh gaya kepemimpinan dan lingkungan kerja terhadap kinerja pegawai TVRI Stasiun Sulawesi Tenggara maka dapat ditarik beberapa kesimpulan sebagai berikut: 1) Gaya kepemimpinan berpengaru signifikan terhadap kinerja pegawai TVRI Stasiun Sulawesi Tenggara. Artinya, semakin baik gaya kepemimpinan yang diterapkan pimpinan maka, akan semakin meningkatkan kinerja pegawai TVRI Stasiun Sulawesi Tenggara dan 2) Lingkungan kerja berpengaruh signifikan terhadap kinerja pegawai TVRI Stasiun Sulawesi Tenggara. Artinya apabila lingkungan kerja baik, maka kinerja pegawai TVRI Stasiun Sulawesi Tenggara akan semakin meningkat.

\section{Saran}

Berdasarkan hasil pembahasan dan kesimpulan penelitian, maka peneliti menyampaikan saran sebagai berikut: 1) TVRI Stasiun Sulawesi Tenggara perlu menerapkan gaya kepemimpinan partisifatif dengan baik terutama dalam pengambilan keputusan secara bersamasama pada kondisi-kondisi tertentu. Penerapan gaya kepemimpinan partisifatif dengan baik diharapkan akan semakin meningkatkan kinerja pegawai; 2) Pimpinan TVRI Stasiun Sulawesi Tenggara, hendaknya terus meningkatkan dan memperhatikan lingkungan kerja agar pegawainya dapat meningkatkan kinerjanya. Sebab hasil penelitian didapatkan bahwa variable lingkungan kerja berpengaruh paling dominan menentukan kinerja pegawai dan 3) Peneliti selanjutnya diharapkan dapat memperluas ruang lingkup dan lokasi penelitian sehingga hasil penelitian dapat diimplementasikan secara umum. Peneliti selanjutnya dapat menggunakan variabel yang lebih bervariasi dengan menambah variabel lainnya yang dapat mempengaruhi kinerja pegawai seperti, budaya organisasi, motivasi, kepuasan kerja, kemampuan, keahlian, loyalitas, disiplin kerja, kepribadian, komitmen dan lain-lain.

\section{DAFTAR PUSTAKA}

A.A. Anwar Prabu Mangkunegara 2010. Manajemen Sumber Daya Manusia Perusahaan. Bandung: PT. Romaja Rosdakarya

Alex S. Nitisemito 2000. Manajemen Personalia: Manajemen Sumber Daya Manusia, Ed. 3. Jakarta: Ghalia Indonesia.

Arif, Ramdhani 2011. Penilaian Kinerja. PT. Sarana Panca Karya Nusa.

Arikunto, S. 2013. Prosedur Penelitian: Suatu Pendekatan Praktik. Jakarta: Rineka Cipta.

Bernardin, H. John dan Joyce E.A Russel. 2003. Human resource management (An Experimental Approach International Edition). Singapore: Mc. Graw-Hill Inc.

Doelhadi, S. 2001. Strategi Dala Pengendalan dan Pengelolaan Stres. Jurnal Anima. Volume XII No. 48.

Febriansyah, Hardino. 2012. Analisis Pengaruh Kepemimpinan, Motivasi dan Lingkungan Kerja Terhadap Kinerja Pegawai Badan Diklat Provinsi Jawa Tengah. Skripsi. Universitas Diponegoro Semarang.

Fretilino Rufino De A.P. 2012 Pengaruh Kepemimpinan, Motivasi dan Lingkungan Kerja Terhadap Kinerja Karyawan Di Grand Manhattan Club. Tesis. Universitas Esa Unggul, Jakarta.

Handoko, T. Hani. 2003. Manajemen Personalia dan Sumber daya Manusia. Yogyakarta: BPFE- Yogyakarta.

Kasmir. 2016. Manajemen Sumber Daya Manusia (Teori dan Praktik). Depok: PT Rajagrafindo Persada 
Jurnal Progres Ekonomi Pembangunan (JPEP)

Volume 5, Nomor 2. Tahun 2020

Page: $1-10$

http://ojs.uho.ac.id/index.php/JPEP

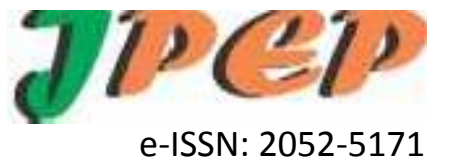

Koopmans, et al. (2014). Improving the individual work performance questionnaire using rasch analysis. J Appl Meas, 15(2), 160-175.

Noack Pariaribo. 2014. Pengaruh Gaya Kepemimpinan dan Motivasi Kerja Terhadap Kepuasan Kerja Serta Dampaknya Terhadap Kinerja Pegawai Pada Badan Perencanan Pembangunan Daerah Di Kabupaten Supiori. Tesis. Universitas Atma Jaya Yogyakarta.

Nova Nurmawilis. 2008. Pengaruh Gaya Kepemimpinan dan Kepuasan Kerja Terhadap Kinerja Karyawan di RSUD Rokan Hulu Propinsi Riau. Tesis Program Pascasarjana Universitas Sumatera Utara Medan.

Marjan. 2020. Pengaruh gaya kepemimpinan, lingkungan kerja dan pemberian insentif terhadap kinerja pegawai TVRI Stasiun Sulawesi Tenggara. Tesis. Universitas Halu Oleo Kendari.

Payaman, J. Simanjuntak. 2011. Pengantar Ekonomi Sumber Daya Manusia. Jakarta: Penerbit FE UI.

Pasolong, Harbani. 2010. Kepemimpinan Birokrasi. Bandung: Alfabeta.

Rani Mariam, 2009, Pengaruh Gaya Kepemimpinan Dan Budaya Organisasi Terhadap Kinerja Karyawan Melalui Kepuasan Kerja Karyawan Sebagai Variabel Intervening Studi Pada Kantor Pusat PT.Asuransi Jasa Indonesia (Persero). Tesis, Universitas Diponegoro Semarang

Rivai, Z., Veithzal, dkk. 2014. Kepemimpinan dan Perilaku Organisasi. Jakarta: Raja Grafindo Persada.

Robbins SP dan Judge 2007. Perilaku Organisasi. Alih Bahasa Drs. Benyamin Molan. Jakarta; Salemba Empat.

Sarwoto. 2010. Dasar-Dasar Organisasi dan Manajemen. Jakarta: Ghalia Indonesia

Siagian S. P. 2002. Kiat Meningkatkan Produktivitas Kerja. Jakarta: PT Rineka Cipta.

Sugiyono. 2014. Metode Penelitian Kuantitatif Kualitatif Dan R\&D. Bandung: CV ALFABETA.

Sukmasari, Hentry. 2011. Pengaruh Kepemimpinan, Motivasi, Insentif, Lingkungan Kerja dan Kepuasan Kerja Terhadap Kinerja Pegawai Dinas Pengelolaan Keuangan dan Aset Daerah Kota Semarang. Tesis. Universitas Dian Nuswantoro Semarang.

Suranta, Sri. 2002. Dampak Motivasi Karyawan Pada Hubungan Antara Gaya Kepemimpinan Dengan Kinerja Karyawan Perusahaan Bisnis. Empirika. Vol 15. No 2. Hal: 116-138.

Sedarmayanti. (2001). Sumber Daya Manusia dan Produktivitas Kerja. Bandung: Mandar Maju.

Sri Kurniawati Padma Dewi, Titi Laras. 2014. Pengaruh Pelatihan, Motivasi Kerja dan Lingkungan Kerja Terhadap Kinerja Karyawan Koperasi Mahasiswa (Kopma) di Kabupaten Sleman. Jurnal Bisnis dan Ekonomi. Universitas Janabadra

Windy Sitorus. 2016. Pengaruh Gaya Kepemimpinan Dan Motivasi Kerja Terhadap Kinerja Pegawai Kementrian Pu Wilayah I Provinsi Lampung. Universitas Lampung. Bandar Lampung 